\title{
Patients opting for breast reconstruction following mastectomy: an analysis of uptake rates and benefit
}

This article was published in the following Dove Press journal:

Breast Cancer:Targets and Therapy

26 February 2013

Number of times this article has been viewed

\section{Marissa M Howard-McNatt \\ Department of General Surgery, Wake Forest School of Medicine, Winston-Salem, NC, USA}

Correspondence: Marissa M HowardMcNatt

Department of General Surgery, Wake Forest School of Medicine, Medical Center Boulevard,

Winston-Salem,

NC 27I57, USA

$\mathrm{Tel}+\mathrm{I} 3367160545$

Fax +I 3367169758

Email mmcnatt@wakehealth.edu

\begin{abstract}
For women with breast cancer who undergo a mastectomy, breast reconstruction offers improved psychological and cosmetic outcomes. We analyzed the rates of breast reconstruction and potential benefits to these women. The review was based on a PubMed search using the terms "reconstruction," "mastectomy," "rates," "benefits," and "breast cancer." Breast-reconstruction rates have continued to rise in recent years; however, there are definite barriers to widespread use of this procedure. These barriers include age, ethnicity, income, tumor characteristics, and the need for adjuvant radiation therapy. There are notable psychological advantages to women who receive breast reconstruction. These women also express an improved quality of life. Breast reconstruction is an acceptable technique for women undergoing mastectomy. It should be offered to all women in an immediate or delayed fashion, with guidance from their physician about the benefits and risks.
\end{abstract}

Keywords: breast reconstruction, breast cancer, rates, benefits

\section{Introduction}

Surgery is one of the main treatments for breast cancer. Its use is evolving as more management options that improve patient satisfaction are offered. Several trials have demonstrated equivalent rates of survival for the treatment of breast cancer with lumpectomy and mastectomy in women with early stage breast cancer. ${ }^{1-3}$ However, several recent studies have reported an increase in the mastectomy rate. ${ }^{4,5}$ Although partly attributed to the increased use of preoperative breast magnetic resonance imaging, the exact cause of the increasing rates noted in these studies is unclear. ${ }^{6}$ Mahmood et al found that women diagnosed in 2008 were more likely to undergo mastectomy than women diagnosed in 2005 (odds ratio 1.17, 95\% confidence interval 1.13-1.21; $P<0.0001$ ). ${ }^{7}$

The options for reconstructive surgery include alloplastic material or implant-based versus autologous tissue transfer. Many plastic surgeons prefer performing a two-stage reconstruction or two-stage delayed reconstruction if implants are used. This method is preferred if the patient's skin and chest-wall tissues are tight and flat. An implanted tissue expander is inserted at the time of the mastectomy under the pectoralis muscle group. Through a tiny valve under the skin, the surgeon injects a saltwater solution at regular intervals over a 4- to 6-month period to fill the expander. A second surgery is done to remove the expander and put in the permanent implant. Implants can be placed without using an expander, but this depends on the patient's breast size and status of their skin.

Autologous or tissue-flap reconstruction is the second type of breast reconstructive option. This uses the patient's own skin, subcutaneous tissue, and muscle to create a breast 
mound. The two most common options include transverse rectus abdominis myocutaneous (TRAM) flap, which uses tissue from the lower abdomen, and the latissimus dorsi flap, which uses tissue from the upper back. TRAM flaps are categorized by their blood supply. Pedicled TRAM flaps can be based on branches from the deep superior epigastric artery and vein. The free TRAM flap is a microsurgical procedure in which the deep inferior epigastric artery and vein are used as the axial pedicle. The latissimus dorsi myocutaneous flap uses the skin island and tissue associated with the latissimus dorsi to create a breast mound. Often, implants are used in conjunction with this flap to add fullness and volume to the reconstruction. Another flap procedure, the deep inferior epigastric perforator flap, uses fat and skin from the same area as in the TRAM flap, but does not use the rectus abdominis muscle to form the breast mound. This method uses a free flap with microsurgical techniques to anastomose the vessels. The gluteal free flap or gluteal artery perforator flap is a newer type of surgery that uses tissue from the buttocks, including the gluteal muscle, to create the breast shape. It is an option for women who cannot or do not wish to use the abdominal sites due to thinness, incisions, failed TRAM or DIEP flap, or other reasons. Table 1 outlines the advantages and disadvantages of each reconstructive type.

For those women who choose to have a mastectomy, breast reconstruction offers a cosmetic advantage, and numerous studies have shown potential psychological benefits as well. ${ }^{8-11}$ Women who undergo mastectomy without breast reconstruction report a loss of perceived femininity, depression, anxiety, and interpersonal, marital, and sexual dysfunction. ${ }^{12}$ Immediate breast reconstruction has also been proven to be oncologically safe. ${ }^{13-15}$ Despite concerns about delay in administration of adjuvant chemotherapy in patients who receive immediate breast reconstruction, several trials have reported no delay in the delivery of systemic therapy after immediate breast reconstruction. ${ }^{16-18}$

Despite the option of immediate or delayed breast reconstruction after mastectomy, its utilization remains limited. The purpose of this review is to determine the rates of breast reconstruction after mastectomy and to analyze the benefits and risks of the procedure as reported in the literature.

\section{Search strategy and selection criteria}

Data for this review were identified by a search of PubMed using the search terms "reconstruction," "mastectomy," "rates," "benefits," and "breast cancer." Relevant references from identified articles were also included. Approximately 380 articles were identified, and their titles and abstracts were screened for relevance. Abstracts, meeting reports, case reports, and very small series were excluded. Only Englishlanguage articles published between 1990 and 2012 were included for analysis.

Table I Breast reconstruction options, including advantages and disadvantages

\begin{tabular}{|c|c|c|c|c|c|}
\hline Type & Specifics & Indications & Contraindications & Advantages & Disadvantages \\
\hline Implant-based & $\begin{array}{l}\text { Tissue expander } \\
\text { or implant under } \\
\text { the pectoralis } \\
\text { muscle }\end{array}$ & $\begin{array}{l}\text { Small breast with } \\
\text { minimal ptosis } \\
\text { Lack of donor tissue } \\
\text { Patient preference }\end{array}$ & $\begin{array}{l}\text { Previous radiation } \\
\text { therapy } \\
\text { Potential for } \\
\text { anticipated } \\
\text { radiation therapy }\end{array}$ & $\begin{array}{l}\text { No donor-site morbidity } \\
\text { Short operation, } \\
\text { admission and recovery }\end{array}$ & $\begin{array}{l}\text { Complications related } \\
\text { to implant (eg, capsular } \\
\text { contracture, implant } \\
\text { migration) } \\
\text { Visits for tissue expansion } \\
\text { and second surgery to } \\
\text { remove expander and } \\
\text { place implant }\end{array}$ \\
\hline Autologous & $\begin{array}{l}\text { Pedicled: TRAM } \\
\text { Free: TRAM, DIEP } \\
\text { Other: gluteal } \\
\text { flaps, thigh flaps }\end{array}$ & $\begin{array}{l}\text { Redundant tissue } \\
\text { Patient preference }\end{array}$ & $\begin{array}{l}\text { Severe comorbidities } \\
\text { Lack of donor tissue } \\
\text { An excess of donor } \\
\text { tissue (eg, } \\
\text { large pannus) }\end{array}$ & $\begin{array}{l}\text { More natural in } \\
\text { appearance and feel } \\
\text { Improved symmetry to } \\
\text { contralateral native breast } \\
\text { Better outcomes in } \\
\text { patients requiring } \\
\text { radiation than } \\
\text { in implant patients }\end{array}$ & $\begin{array}{l}\text { Longer operation, } \\
\text { admission, and recovery } \\
\text { Increased blood loss in } \\
\text { the surgery } \\
\text { Donor site complications } \\
\text { Potential for partial or } \\
\text { total flap loss }\end{array}$ \\
\hline Combination & $\begin{array}{l}\text { Pedicled latissimus } \\
\text { dorsi flap with } \\
\text { an implant }\end{array}$ & $\begin{array}{l}\text { Not a candidate } \\
\text { for autologous } \\
\text { reconstruction alone } \\
\text { Previous radiation } \\
\text { treatments to the chest } \\
\text { Patient preference }\end{array}$ & $\begin{array}{l}\text { Atrophic or absent } \\
\text { latissimus dorsi } \\
\text { muscle }\end{array}$ & $\begin{array}{l}\text { More natural appearance } \\
\text { and feel than } \\
\text { implant alone } \\
\text { Latissimus dorsi muscle } \\
\text { gives increased protection } \\
\text { and vascularity } \\
\text { against radiation }\end{array}$ & $\begin{array}{l}\text { Morbidity at the donor } \\
\text { site } \\
\text { More invasive than } \\
\text { implant-based surgery }\end{array}$ \\
\hline
\end{tabular}

Abbreviations: TRAM, transverse rectus abdominis myocutaneous; DIEP, deep inferior epigastric perforator. 


\section{Rates}

Low rates for breast reconstruction in the past were primarily due to concerns about compromising surgical resection for reconstruction, and the possibility of decreasing detection of local recurrences. ${ }^{19}$ The first large study to look at breast-reconstruction rates used the information from the National Cancer Database to examine patients from 1985 to 1990 and 1994 to 1995 in the United States. The study found that between 1985 and 1990, 3.4\% of mastectomy patients had early or immediate reconstruction. This rate increased to $8.3 \%$ in $1994-1995 .{ }^{20} \mathrm{~A}$ second study from Connecticut found that breast-reconstruction rates increased from $9 \%$ in 1992 to $16 \%$ in $1996 .^{21}$

In 1998, the Women's Health and Cancer Rights Act was passed, requiring group health plans and individual health insurance policies to pay for reconstruction after mastectomy. ${ }^{22}$ Since this law went into effect, the rate of breast reconstructive surgery has slightly increased. An analysis of data from the Nationwide Inpatient Sample from 1999 to 2003 showed the 5-year average reconstruction rate to be $23.6 \%$ during that time frame ${ }^{23}$ Breast-reconstruction rates have continued to rise in recent years. A California study found that postmastectomy reconstruction rose from $24.8 \%$ in 2003 to $29.2 \%$ in $2007 .{ }^{24}$ It is important to note, however, that these rates can be variable. Christian et al found the reconstruction rate to be $42 \%$ in patients treated at National Comprehensive Cancer Network multidisciplinary hospitals, ${ }^{25}$ while some single institutions have immediate and delayed reconstruction rates as high as $59 \%{ }^{26}$

Internationally, breast-reconstruction rates have been low, and Canada has had a particularly low rate of breast reconstruction. ${ }^{27}$ Baxter and colleagues found a reconstruction rate of $7.9 \%$ in 1995 in Ontario, ${ }^{28}$ and in Nova Scotia the rate was found to be $3.8 \%$ between 1991 and $2001 .{ }^{29}$ There has not been a more recent evaluation in Canada. Australia, Denmark, and England reported national rates of breast reconstruction of 9\% (1982-2000), 14\% (1999-2006), and $16.5 \%$ (2006-2009), respectively. ${ }^{30-32}$

\section{Factors associated with the use of breast reconstruction}

What factors influence the utilization of breast reconstruction? The most common factors cited in the literature relate to age, race, socioeconomic background, stage, and physician practice. Age less than 50 years was a constant and best predictor of having breast reconstruction. . $^{20,21,24,25,31-34}$ Some physicians fear offering breast reconstruction to older women, due to their coexisting morbidities and perceived increase in complications. However, breast reconstruction is a safe and feasible option in older patients. We found in our review of 89 women over 60 years of age that there was only an $11 \%$ complication rate, equivalent to all ages. ${ }^{35}$ The patient's biological age and comorbidities need to be considered, but women of all ages with breast cancer should be offered breast reconstruction.

Income disparity has been associated with decreased use of breast reconstruction. Morrow et al showed that in 2001, women who made more than US $\$ 40,000$ were more likely to undergo breast reconstruction. ${ }^{20}$ Other studies have shown that women with commercial insurance had a threefoldhigher likelihood of undergoing immediate reconstruction compared to those without insurance. ${ }^{34} \mathrm{~A}$ Southern California study found that patients with private insurance were ten times more likely to undergo reconstruction than patients with Medi-Cal insurance..$^{24}$ In contrast, patients who are considered financially indigent and who receive their care at a university-based public hospital are more likely to have breast reconstruction. ${ }^{36}$ Internationally in Western Australia and England, studies that used area code or educational level as proxies for socioeconomic status similarly found that women with less income were less likely to have breast reconstruction. . $^{30,31}$

Ethnicity has been shown to be a factor in breast reconstruction. In studies by Tseng et al and Morrow et al, AfricanAmerican women were one-third as likely to undergo breast reconstruction. ${ }^{37,38}$ Rosson et al and Alderman et al found that reconstruction was lower in African-American women, approximately half the rate of whites. ${ }^{33,39}$ Kruper et al found that Asian women were one-third as likely to undergo breast reconstruction as compared to white women..$^{24}$ Levine et al found that there was a lower rate of breast reconstruction in Asian women (34\%) compared with Hispanic women (48\%), despite the same access to available services. ${ }^{36}$ The ethnic disparity in breast reconstruction is complicated.

Geographic variation has also been observed in breast reconstruction rates. In a Surveillance Epidemiology and End Results database study, Agarwal et al found that the odds ratio of receiving breast reconstruction was 2.8 in the Atlanta metropolitan area to 0.60 in the Seattle area (reference point of San Francisco).$^{40}$ They also noted that patients living in a rural area had a lower likelihood of receiving breast reconstruction $(P<0.001)$. In Ontario, breast reconstruction occurred at twice the rate in Toronto when compared to the rest of the province. ${ }^{27,28}$ Regional variation has also been seen in England, where the reconstruction rate varies from 8.4\% 
to $31.9 \%$, depending on the region. ${ }^{31}$ It has been speculated that this regional variation is due to reimbursement policy, education, and access to care and a plastic surgeon. ${ }^{34,37,40}$ Finally, it should be emphasized that this is the personal choice of the patient. The patient should be given all the available information and then she can choose if she wants breast reconstruction.

\section{Tumor characteristics}

A patient's stage of disease plays a pivotal role in the incidence of breast reconstruction. Patients with ductal carcinoma in situ or stage I disease are more likely to undergo breast reconstruction..$^{20,27,25,33}$ For example, Hershman et al found that women with ductal carcinoma in situ were more likely to have breast reconstruction at the time of mastectomy when compared to patients with invasive breast cancers (44\% vs 28\%). ${ }^{34}$ However, a Washington University study showed that tumor stage was not related to breast-reconstruction utilization. ${ }^{26}$ This result is likely institution-specific. Plastic surgeons have also examined factors associated with local recurrence after skin-sparing mastectomy and immediate breast reconstruction in patients with invasive breast cancer. In their review of 565 women who underwent immediate breast reconstruction, Carlson et al found that factors associated with a longer disease-free survival include tumor grade and administration of adjuvant radiotherapy. ${ }^{41}$ Others have found that grade along with tumor size and the extent of axillary lymph-node involvement predict local recurrence. ${ }^{42}$

\section{Adjuvant therapies}

The need for adjuvant treatment has affected the management and outcomes of breast reconstruction, and delays the initiation of chemotherapy between 4 to 6 weeks after surgery. However, several authors have found no such delay in initiating chemotherapy. ${ }^{16,26,43-45}$ Wilson and colleagues compared patients with immediate reconstruction with those undergoing mastectomy without reconstruction and those undergoing a lumpectomy. ${ }^{46}$ They concluded that there were no delays between the three groups. Alderman et al looked at women at National Comprehensive Cancer Network hospitals and found that immediate reconstruction was associated with an increase in the time to chemotherapy initiation compared with all other treatment strategies among women less than 60 years of age. However, for women over 60 years, the time to chemotherapy was shorter among women receiving reconstruction (immediate or delayed) compared with those undergoing lumpectomy or mastectomy alone. ${ }^{47}$ Another study showed an increase in the number of wound complications in patients after immediate breast reconstruction compared to patients who did not have reconstruction. ${ }^{48}$ However, they found that this did not delay the initiation of chemotherapy, nor did it increase the risk of complications. Infections were the most common reason for early removal of tissue expanders in patients, the majority of whom were receiving chemotherapy. ${ }^{49}$

Neoadjuvant chemotherapy is an established modality in the treatment of breast cancer. It can reduce the tumor burden in the breast and the axilla, thereby offering women less extensive operations. ${ }^{50}$ Few studies have addressed the use of neoadjuvant chemotherapy and breast reconstruction. One small study of stage III patients showed no delay in adjuvant therapy in women who had immediate breast reconstruction, but the perioperative morbidity rate was $14 \% .{ }^{51}$ However, Warren Peled et al found no difference in reoperation, skin necrosis, implant loss, or seroma after immediate breast reconstruction when comparing patients who received neoadjuvant and adjuvant chemotherapy. ${ }^{52} \mathrm{~A}$ recent study by $\mathrm{Hu}$ et al compared 180 patients who received neoadjuvant chemotherapy and 485 patients who underwent mastectomy before chemotherapy. ${ }^{53}$ They found that patients who receive neoadjuvant chemotherapy are less likely to undergo immediate reconstruction and are no more likely to have delayed breast reconstruction than patients who have surgery before they receive chemotherapy. They speculated that their findings could have been due to treatment fatigue.

Radiation therapy offers increased locoregional control in patients with locally advanced disease, but complicates breast reconstruction. Two primary reconstruction options are available to women who undergo mastectomy. One option is an autologous tissue reconstruction utilizing myocutaneous tissue flaps as a breast mound, and the alternative option is immediate tissue-expander placement at the time of mastectomy, followed by expansion and subsequent exchange for a permanent implant later. Radiation therapy has been associated with implant loss and flap complications. ${ }^{54}$ Studies have also documented poor cosmetic outcomes ${ }^{55}$ and increased complication rates for implant-based reconstruction in the irradiated breast. The Cleveland Clinic reviewed 560 patients undergoing 733 expander-based reconstructions. ${ }^{56}$ They found that radiation therapy was associated with increased complications, with multivariate analysis identifying radiation therapy as the most significant factor associated with complications (odds ratio 4.99, $P<0.001$ ). Prospective data from the Michigan Breast Reconstruction Outcome Study confirm the above 
findings: radiation therapy was associated with increased rates of complications ( $68 \%$ vs $31 \%, P=0.006)$ and greater rates of reconstruction failures $(37 \%$ vs $8 \%, P=0.07)$ when patients underwent postmastectomy radiotherapy. ${ }^{57}$

Due to the complication rate with implants, many plastic surgeons feel that autologous reconstruction is superior to implant-based reconstruction in the irradiated chest. $^{58,59}$ TRAM flap reconstruction is the most common technique used for autologous reconstruction. A study from the University of Pennsylvania evaluated 500 patients and found the overall complication rate when using TRAM flap reconstruction to be approximately $20 \%$ with smoking, peripheral vascular disease, and obesity associated with infection and necrosis, whereas radiation therapy was only associated with seroma development. ${ }^{60}$ Due to these conflicting data, some centers favor postponing breast reconstruction if postmastectomy radiation therapy is likely, ${ }^{61}$ whereas others routinely perform immediate reconstruction despite the need for radiation. ${ }^{62}$ The MD Anderson Cancer Center has championed the delayed-immediate reconstruction technique. ${ }^{63}$ Patients who desire reconstruction undergo immediate tissue-expander placement followed by either reconstruction within 2 weeks if radiation is not required, or if radiation is required, deflation of the expander before radiation begins, reinflation after delivery of radiation, and subsequently delayed reconstruction.

\section{Benefits}

The loss of a breast is psychologically traumatic for many women. ${ }^{64}$ Breast cancer can have a negative impact on a woman's body image and sexuality. ${ }^{65}$ Immediate breast reconstruction is potentially psychologically beneficial by restoring a women's body image. ${ }^{12,66}$ Al-Ghazal reported improved overall satisfaction, body image, self-esteem, feeling of attractiveness, and decreased anxiety and depression in immediate-reconstruction patients compared with delayed-reconstruction patients. ${ }^{67}$ However, reconstructive breast surgery has been shown to negatively impact body image. Janz et al reported body image to be poorest among women who had a mastectomy with reconstruction, ${ }^{68}$ and Collins et al found that at 6 months postsurgery, women who had undergone reconstruction had worse body image compared with those who only had a mastectomy. ${ }^{69}$ In a study by Fobair et al, women who were considering or had already undergone breast reconstruction had the most body image concerns during the first few months following their cancer diagnosis. ${ }^{70}$ In contrast, in a study of 419 women with breast cancer under 40, Rosenberg and colleagues found that reconstructive surgery seems to mitigate the concerns over body image in this age-group. ${ }^{71}$

Quality of life tends to improve in women who have undergone reconstructive surgery as time progresses. In a study of women who received implant-based reconstruction, their quality of life was similar to the general population after 1 year of follow-up. ${ }^{64}$ Another study found that as early as 3 weeks after surgery, satisfaction, psychosocial well-being, and sexual well-being after TRAM or deep inferior epigastric perforator flap reconstruction were statistically significant and clinically meaningful to the patient. ${ }^{72}$ Heneghan et al found that in immediate breast-reconstruction patients, their quality of life was comparable to a group of age-matched women who underwent breast-conserving surgery. ${ }^{73}$ Researchers in Belgium noted that patients who received breast-conserving treatment or mastectomy with reconstruction had similar results of quality of life, but cosmetic outcome was better after skin-sparing mastectomy, as assessed by the clinical team. ${ }^{74}$

\section{Conclusion}

In conclusion, breast reconstruction after mastectomy has slowly increased over the past decade. The decision to undergo reconstructive surgery is complex. There are many factors associated with the receipt of breast reconstruction. Women who are younger than 50 years are more likely to receive breast reconstruction; however, breast reconstruction in older patients is considered safe. Women who live in an urban setting are more likely to undergo breast reconstruction. This may be related to the availability of a plastic surgeon. A woman's income is also a factor in receiving breast reconstruction. Finally, minority women are less likely to receive breast reconstruction. This factor is complicated and may be related to socioeconomic factors. When women of all races and classes are given the opportunity for breast reconstruction, more patients choose this option. Tumor-related factors are associated with the stage of disease and the need for radiation therapy. The benefits of breast reconstruction potentially include improved body image, self-esteem, well-being, and a possible survival advantage. Breast cancer surgery is a complex process of decision-making involving the patient, surgeon, and plastic surgeon. In the end, it is the patient's choice how she should proceed. The patient should be well educated about the available options as well as the complications and benefits. All patients who face a mastectomy regardless of age, income status, or race should be offered breast reconstructive surgery. 


\section{Disclosure}

The author reports no conflicts of interest in this work.

\section{References}

1. Fisher B, Anderson S, Redmond CK, Wolmark N, Wickerham DL, Cronin WM. Reanalysis and results after 12 years of follow-up in a randomized clinical trial comparing total mastectomy with lumpectomy with or without irradiation in the treatment of breast cancer. $N$ Engl $J$ Med. 1995;333:1456-1461.

2. Veronesi U, Banfi A, Del Vecchio M, et al. Comparison of Halsted mastectomy with quadrantectomy, axillary dissection and radiotherapy in early breast cancer: long-term results. Eur J Cancer Clin Oncol. 1986;22:1085-1089.

3. Bland KI, Menck HR, Scott-Conner CE, Morrow M, Winchester DJ, Winchester DP. The National Cancer Data Base 10-year survey of breast carcinoma treatment at hospitals in the United States. Cancer. 1998;83:1262-1273.

4. Gomez SL, Lichtensztajn D, Kurian AW, et al. Increasing mastectomy rates for early-stage breast cancer? Population-based trends from California. J Clin Oncol. 2010;28:e155-e157.

5. McGuire KP, Santillan AA, Kaur P, et al. Are mastectomies on the rise? A 13-year trend analysis of the selection of mastectomy versus breast conservation therapy in 5865 patients. Ann Surg Oncol. 2009;16:2682-2690.

6. Katipamula R, Degnim AC, Hoskin T, et al. Trends in mastectomy rates at the Mayo Clinic Rochester: effect of surgical year and preoperative magnetic resonance imaging. J Clin Oncol. 2009;27:4082-4088.

7. Mahmood U, Hanlon AL, Koshy M, et al. Increasing national mastectomy rates for the treatment of early stage breast cancer. Ann Surg Oncol. Epub November 8, 2012.

8. Al-Ghazal SK, Fallowfield L, Blamey RW. Comparison of psychological aspects and patient satisfaction following breast conserving surgery, simple mastectomy and breast reconstruction. Eur J Cancer. 2000;36: 1938-1943.

9. Brandberg Y, Malm M, Blomqvist L. A prospective and randomized study, "SVEA," comparing effects of three methods for delayed reconstruction on quality of life, patient-defined problem areas of life, and cosmetic result. Plast Reconstr Surg. 2000;105:66-74.

10. Rowland JH, Desmond KA, Meyerowitz BE, Belin TR, Wyatt GE, Ganz PA. Role of breast reconstructive surgery in physical and emotional outcomes among breast cancer survivors. $J$ Natl Cancer Inst. 2000;92:1422-1429.

11. Schain WS, Wellisch DK, Pasnau RO, Landsverk J. The sooner the better: a study of psychological factors in women undergoing immediate versus delayed breast reconstruction. Am J Psychiatry. 1985;142: $40-46$.

12. Wilkins EG, Cederna PS, Lowery JC, et al. Prospective analysis of psychosocial outcomes in breast reconstruction: one-year postoperative results from the Michigan Breast Reconstruction Outcome Study. Plast Reconstr Surg. 2000;106:1014-1025.

13. Foster RD, Esserman LJ, Anthony JP, Hwang ES, Do H. Skin-sparing mastectomy and immediate breast reconstruction: a prospective cohort for the treatment of advanced stages of breast carcinoma. Ann Surg Oncol. 2002;9:462-466.

14. Howard MA, Polo K, Pusic AL, et al. Breast cancer local recurrence after mastectomy and TRAM flap reconstruction: incidence and treatment options. Plast Reconstr Surg. 2006;118:1381-1386.

15. Murphy RX Jr, Wahab S, Rovito PF. Impact of immediate reconstruction on the local recurrence of breast cancer after mastectomy. Ann Plast Surg. 2003;50:333-338.

16. Allweis TM, Boisvert ME, Otero SE, Perry DJ, Dubin NH, Priebat DA. Immediate reconstruction after mastectomy for breast cancer does not prolong the time to starting adjuvant chemotherapy. Am J Surg. 2002; 183:218-221.

17. McCarthy CM Pusic AL, Sclafani L, et al. Breast cancer recurrence following prosthetic, postmastectomy reconstruction: incidence, detection, and treatment. Plast Reconstr Surg. 2008;121:381-388.
18. Reddy S, Colakoglu S, Curtis MS, et al. Breast cancer recurrence following postmastectomy reconstruction compared to mastectomy with no reconstruction. Ann Plast Surg. 2011;66:466-471.

19. Lester LJ. A critical viewpoint by a general surgeon toward reconstructive surgery after mastectomy. Clin Plast Surg. 1979;6:15-17.

20. Morrow M, Scott SK, Menck HR, Mustoe TA, Winchester DP. Factors influencing the use of breast reconstruction postmastectomy: a National Cancer Database Study. J Am Coll Surg. 2001;192:1-8.

21. Polednak AP. How frequent is postmastectomy breast reconstructive surgery? A study linking two statewide databases. Plast Reconstr Surg. 2001;108:73-77.

22. Department of Labor. Health plans and benefits: women's health and cancer rights protections. Available from: http://www.dol.gov/dol/topic/ health-plans/womens.htm. Accessed January 21, 2012.

23. Reuben B, Manwaring J, Neumayer LA. Recent trends and predictors in immediate breast reconstruction after mastectomy in the United States. Am J Surg. 2009;198:237-243.

24. Kruper L, Holt A, Xu XX, et al. Disparities in reconstruction rates after mastectomy: Patterns of care and factors associated with the use of breast reconstruction in Southern California. Ann Surg Oncol. 2011;18: 2158-2165.

25. Christian CK, Niland J, Edge SE, et al. A multi-institutional analysis of the socioeconomic determinants of breast reconstruction: a study of the National Comprehensive Cancer Network. Ann Surg. 2006;243: 241-249.

26. Elmore L, Myckatyn TM, Gao F, et al. Reconstruction patterns in a single institution cohort of women undergoing mastectomy for breast cancer. Ann Surg Oncol. 2012;19:3223-3229.

27. Platt J, Baxter N, Zhong T. Breast reconstruction after mastectomy for breast cancer. CMAJ. 2011;183:2109-2116.

28. Baxter N, Goel V, Semple JL. Utilization and regional variation of breast reconstruction in Canada. Plast Reconstr Surg. 2005;115:338-339.

29. Barnsley GP, Sigurdson L, Kirkland S. Barriers to breast reconstruction after mastectomy in Nova Scotia. Can J Surg. 2008;51:447-452.

30. Hall Se, Holman CDJ. Inequalities in breast cancer reconstructive surgery according to social and locational status in Western Australia. Eur J Surg Oncol. 2003;29:519-525.

31. Jeevan R, Cromwell DA, Browne JP, et al. Regional variation in the use of immediate breast reconstruction after mastectomy for breast cancer in England. Eur J Surg Oncol. 2010;26:750-755.

32. Hvilsom GB, Hölmich LR, Frederiksen K, Steding-Jessen M, Friis S, Dalton SO. Socioeconomic position and breast reconstruction in Danish women. Acta Oncol. 2011;50:265-273.

33. Alderman AK, McMahon L, Wilkins EG. The national utilization of immediate and early delayed breast reconstruction and the effect of sociodemographic factors. Plast Reconstr Surg. 2003;111:695-703.

34. Hershman DL, Richards CA, Kalinsky K, et al. Influence of health insurance, hospital factors and physician volume on receipt of immediate post-mastectomy reconstruction in women with invasive and non-invasive breast cancer. Breast Cancer Res Treat. 2012;136: 535-545.

35. Howard-McNatt M, Forsberg C, Levine EA, DeFranzo A, Marks M, David L. Breast cancer reconstruction in the elderly. Am Surg. 2011;77: $1640-1643$.

36. Levine SM, Levine A, Raghubir J, Levine JP. A 10-year review of breast reconstruction in a university-based public hospital. Ann Plast Surg. 2012;69:376-378

37. Tseng JF, Kronowitz SJ, Sun CC, et al. The effect of ethnicity on immediate breast reconstruction rates after mastectomy for breast cancer. Cancer. 2004;101:1514-1523.

38. Morrow M, Mujahid M, Lantz PM, et al. Correlates of breast reconstruction: results from a population-based study. Cancer. 2005;104: 2340-2346.

39. Rosson GD, Singh NK, Ahuja N, Jacobs LK, Chang DC. Multilevel analysis of the impact of community vs patient factors on access to immediate breast reconstruction following mastectomy in Maryland. Arch Surg. 2008;143:1076-1081. 
40. Agarwal S, Pappas L, Neumayer L, Agarwal J. An analysis of immediate postmastectomy breast reconstruction frequency using the Surveillance, Epidemiology, and End Results Database. Breast J. 2011;17: 352-358.

41. Carlson GW, Styblo TM, Lyles RH, et al. Local recurrence after skinsparing mastectomy: tumor biology or surgical conservatism? Ann Surg Oncol. 2003;10:108-112.

42. Langstein HN, Cheng MH, Singletary SE, et al. Breast cancer recurrence after immediate breast reconstruction: patterns and significance. Plast Reconstr Surg. 2003;111:712-720.

43. Rey P, Martinelli G, Petit JY, et al. Immediate breast reconstruction and high-dose chemotherapy. Ann Plast Surg. 2005;55:250-254.

44. Taylor CW, Kumar S. The effect of immediate breast reconstruction on adjuvant chemotherapy. Breast. 2005;14:18-21.

45. Caffo O, Cazzolli D, Scalet A, et al. Concurrent adjuvant chemotherapy and immediate breast reconstruction with skin expanders after mastectomy for breast cancer. Breast Cancer Res Treat. 2000;6: 267-275.

46. Wilson CR, Brown IM, Weiller-Mithoff E, George WD, Doughty JC. Immediate breast reconstruction does not lead to a delay in the delivery of adjuvant chemotherapy. Eur J Surg Oncol. 2004;30:624-627.

47. Alderman AK, Collins ED, Schott A, et al. The impact of breast reconstruction on the delivery of chemotherapy. Cancer. 2010;116: 1791-1800.

48. Mortenson MM, Schneider PD, Khatri VP, et al. Immediate breast reconstruction after mastectomy increases wound complications: however, initiation of adjuvant chemotherapy is not delayed. Arch Surg. 2004;139:988-991.

49. Disa JJ, Ad-E1 DD, Cohen SM, Cordeiro PG, Hidalgo DA. The premature removal of tissue expanders in breast reconstruction. Plast Reconstr Surg. 1999;104:1662-1665.

50. Van Nes JG, Putter H, Julien JP, et al. Preoperative chemotherapy is safe in early breast cancer, even after 10 years of follow-up; clinical and translational results from the EORTC trial 10902. Breast Cancer Res Treat. 2009;115:101-113.

51. Sultan MR, Smith ML, Estabrook A, Schnabel F, Singh D. Immediate breast reconstruction in patients with locally advanced disease. Ann Plast Surg. 1997;38:345-349.

52. Warren Peled A, Itakura K, Foster RD, et al. Impact of chemotherapy on postoperative complications after mastectomy and immediate breast reconstruction. Arch Surg. 2010;145:880-885.

53. Hu YY, Weeks CM, In H, et al. Impact of neoadjuvant chemotherapy on breast reconstruction. Cancer. 2011;117:2833-2841.

54. Evans GR, Schusterman MA, Kroll SS, et al. Reconstruction and the radiated breast: is there a role for implants? Plast Reconstr Surg. 1995;96:1111-1115.

55. Ascherman JA, Hanasono MM, Newman MI, Hughes DB. Implant reconstruction in breast cancer patients treated with radiation therapy. Plast Reconstr Surg. 2006;117:359-365

56. Berry T, Brooks S, Sydow N, et al. Complication rates of radiation on tissue expander and autologous tissue breast reconstruction. Ann Surg Oncol. 2010;17 Suppl 3:202-210.

57. Krueger EA, Wilkins EG, Strawderman M, et al. Complications and patient satisfaction following expander/implant breast reconstruction with and without radiotherapy. Int J Radiat Oncol Biol Phys. 2001;49: 713-721.
58. Kronowitz SJ, Robb GL. Radiation therapy and breast reconstruction: a critical review of the literature. Plast Reconstr Surg. 2009;124: 395-408.

59. Shah C, Kundu N, Arthur D, Vicini F. Radiation therapy following postmastectomy reconstruction: a systematic review. Ann Surg Oncol. Epub October 8, 2012.

60. Selber JC, Kurichi JE, Vega SJ, Sonnad SS, Serletti JM. Risk factors and complications in free TRAM flap breast reconstruction. Ann Plast Surg. 2006;56:492-497.

61. Javaid M, Song F, Leinster S, Dickson MG, James NK. Radiation effects on the cosmetic outcomes of immediate and delayed autologous breast reconstruction: an argument about timing. J Plast Reconstr Aesthet Surg. 2006;59:16-26.

62. Azzawi K, Ismail A, Earl H, Forouhi P, Malata CM. Influence of neoadjuvant chemotherapy on outcomes of immediate breast reconstruction. Plast Reconstr Surg. 2010;126:1-11.

63. Kronowitz SJ, Hunt KK, Kuerer HM, et al. Delayed-immediate breast reconstruction. Plast Reconstr Surg. 2004;113:1617-1628.

64. Edstrom-Elder E, Brandberg Y, Björklund T, et al. Quality of life and patient satisfaction in breast cancer patients after immediate breast reconstruction: a prospective study. Breast. 2005;14:201-208.

65. Fernández-Frías AM, Aguilar J, Sánchez JA, Merck B, Piñero A, Calpena R. Immediate reconstruction after mastectomy for breast cancer: which factors affect its course and final outcome? J Am Coll Surg. 2009;208:126-133.

66. Knottenbelt A, Spauwen PHM, Wobbes TH. The oncological implications of immediate breast reconstruction. Eur J Surg Oncol. 2004;30: 829-833.

67. Al-Ghazal SK, Sully L, Fallowfield L, Blamey RW. The psychological impact of immediate rather than delayed breast reconstruction. Eur $J$ Surg Oncol. 2000;26:17-19.

68. Janz NK, Mujahid M, Lantz PM, et al. Population-based study of the relationship of treatment and sociodemographics on quality of life for early stage breast cancer. Qual Life Res. 2005;14:1467-1479.

69. Collins KK, Liu Y, Schootman M, et al. Effects of breast cancer surgery and surgical side effects on body image over time. Breast Cancer Res Treat. 2011;126:167-176.

70. Fobair P, Stewart SL, Chang S, D’Onofrio C, Banks PJ, Bloom JR. Body image and sexual problems in young women with breast cancer. Psychooncology. 2006;15:579-594.

71. Rosenberg SM, Tamimi RM, Gelber S, et al. Body image in recently diagnosed young women with early breast cancer. Psychooncology. Epub November 7, 2012.

72. Zhong T, McCarthy C, Min S, et al. Patient satisfaction and healthrelated quality of life after autologous tissue breast reconstruction: a prospective analysis of early postoperative outcomes. Cancer. 2012;118:1701-1709.

73. Heneghan HM, Prichard RS, Lyons R, et al. Quality of life after immediate breast reconstruction and skin-sparing mastectomy - a comparison with patients undergoing breast conserving surgery. Eur J Surg Oncol. 2011;37:937-943.

74. Cocquyt VF, Blondeel PN, Depypere HT, et al. Better cosmetic results and comparable quality of life after skin-sparing mastectomy and immediate autologous breast reconstruction compared to breast conservative treatment. Br J Plast Surg. 2003;56:462-470.
Breast Cancer: Targets and Therapy

\section{Publish your work in this journal}

Breast Cancer: Targets and Therapy is an international, peerreviewed open access journal focusing on breast cancer research, identification of therapeutic targets and the optimal use of preventative and integrated treatment interventions to achieve improved outcomes, enhanced survival and quality of life for the cancer patient.

\section{Dovepress}

View the full aims and scopes of this journal here. The manuscript management system is completely online and includes a very quick and fair peer-review system, which is all easy to use. Visit http:// www.dovepress.com/testimonials.php to read real quotes from published authors. 